\title{
INTERNATIONAL PLATO SOCIETY
}

In 1986, a small group of Platonic scholars met for the first Symposium Platonicum (on Plato's later dialogues) and formed the project of holding similar symposia on a triennial basis. The second Symposium, on the Phaedrus, duly took place in Perugia in 1989. During this meeting, the hundred or so scholars present established the International Plato Society.

The aim of the Society is to promote the study of Plato across the world, especially through the Symposia themselves, through the publication of the Proceedings of the Symposia, and through the dissemination of information about recent and current work on Plato. The Society owes no allegiance to any particular school or mode of interpretation. Full membership is open to any scholar who has published at least one substantial article - or completed a doctoral dissertation (or equivalent) - on Plato within the last fifteen years, and associate membership to anyone currently working towards a doctoral dissertation (or equivalent) in this field.

The Third Symposium Platonicum took place in late August 1992, in Bristol, on the subject of the Politicus. The meeting, which was attended by more than a third of the current membership of 350, saw the launch of the first volume in a new series, International Plato Studies : Understanding the Phaedrus. Proceedings of the II Symposium Platonicum, edited by L. Rossetti (Sankt Augustin, Academia Verlag, 328 p., hard cover, DM 98). The series will include not only the Proceedings of future Symposia, but also independent monographs on Plato, and reprints of books on Plato presently out of print. Scholars worldwide are invited to send their manuscripts to the President of the I.P.S., Professor Tomás Calvo, Universidad de Granada, Facultad de Letras, Departamento de Filosofia, Campus de Cartuja, E-18011 GRANADA, Spain.

All other correspondence, including applications for membership of the I.P.S., should also be sent to Professor Calvo.

The Fourth Symposium Platonicum, on the Timaeus and Critias, will be held in Granada in 1995. 